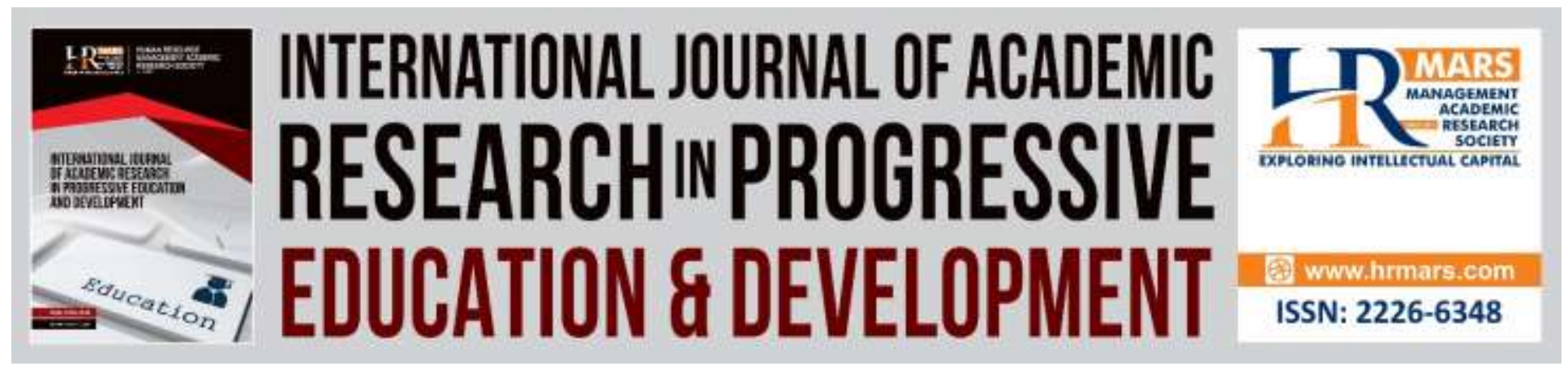

\title{
Board Structure and Corporate's Performance: Evidence from Private Education Companies
}

Mohd Waliuddin Mohd Razali, Josephine Yau Tan Hwang, Mohd Uzairi Ahmad Hajazi and Janifer Lunyai

To Link this Article: http://dx.doi.org/10.6007/IJARPED/v8-i4/6450

DOI: $10.6007 /$ IJARPED/v8-i4/6450

Received: 10 Sept 2019, Revised: 18 Sept 2019, Accepted: 01 Oct 2019

Published Online: 20 Oct, 2019

In-Text Citation: (Razali, Hwang, Hajazi, \& Lunyai, 2019)

To Cite this Article: Razali, M. W. M., Hwang, J. Y. T., Hajazi, M. U. A., \& Lunyai, J. (2019). Board Structure and Corporate's Performance: Evidence from Private Education Companies. International Journal of Academic Research in Progressive Education and Development, 8(4), 141-156.

\section{Copyright: (C) 2019 The Author(s)}

Published by Human Resource Management Academic Research Society (www.hrmars.com)

This article is published under the Creative Commons Attribution (CC BY 4.0) license. Anyone may reproduce, distribute, translate and create derivative works of this article (for both commercial and non-commercial purposes), subject to full attribution to the original publication and authors. The full terms of this license may be seen

at: http://creativecommons.org/licences/by/4.0/legalcode

Vol. 8(4) 2019, Pg. 141- 156

http://hrmars.com/index.php/pages/detail/IJARPED

JOURNAL HOMEPAGE

Full Terms \& Conditions of access and use can be found at http://hrmars.com/index.php/pages/detail/publication-ethics 


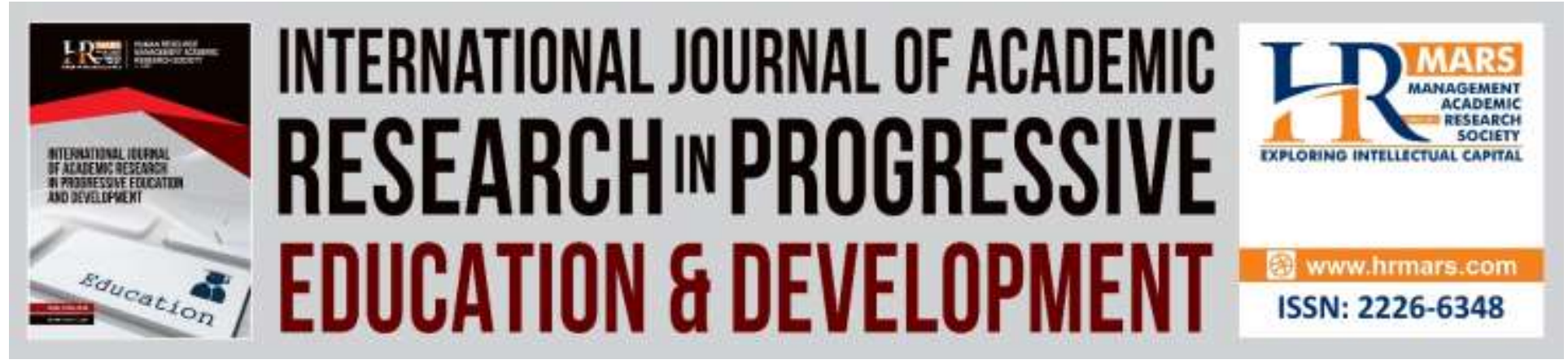

\title{
Board Structure and Corporate's Performance: Evidence from Private Education Companies.
}

\author{
Mohd Waliuddin Mohd Razali1 \& 2 , Josephine Yau Tan Hwang², \\ Mohd Uzairi Ahmad Hajazi ${ }^{2}$ and Janifer Lunyai ${ }^{2}$ \\ ${ }^{1}$ Faculty of Economics and Management, Universiti Kebangsaan Malaysia (UKM), 43600 UKM, \\ Bangi Selangor, Malaysia, ${ }^{2}$ Faculty Economic and Business, Universiti Malaysia Sarawak, \\ 94300 Kota Samarahan, Sarawak, Malaysia \\ Email:walirazali@yahoo.com,mrmwaliuddin@unimas.my
}

\begin{abstract}
This paper investigates the effect of board structure of Malaysian private educational companies towards their firm's corporate performance. The average board size in this study is three and the percentage of women on board is about $40 \%$. In addition, seventy six percent of the firm is having women as their director. By examining the relationship between board structure (board size and, woman on board) and the firm performance, our study shows that board size has a significant negative relationship with firm performance. However, women on board show significant positive effect on corporate performance. Our results imply that larger board will reduce firm performance, while women on board may create higher firm performance. These findings suggest that firm with large board size may encounter more agency issues in monitoring and controlling the members on board. On the other hand, firms with more women on board may have better corporate performance, as claimed by women are good in term of understand the market needs and bringing creativity and quality solution in decision making. More women in the board in some extent improve corporate performance in private education companies. The study could be extended with variables such as ownership, board meeting, director social network and other on corporate performance that could give significant interest of many stakeholders.
\end{abstract}

Keywords: Board Structure, Board Size, Women on board, Corporate Performance, Private Education Sector

\section{Introduction}

As a vital part of corporate governance internal control mechanism, assessing board of directors has gathered a significant interest from policy makers, practitioners, and academician, especially after a number of high profile failures of big corporation in the last two decades. The 
effectiveness of board of directors attracts much attention, with the debate on how factors such as board size and diversity influence firm's performance become among key focus areas. Hwang et al. (2014) argued that a corporation with a larger board size should be more efficient because there are more directors to monitor and handle the management with more knowledge and diverse background. A larger board size would also bring more opportunity to link with other organizations and access external resources (Kula, 2005). On the other hand, Jensen (2012) suggested that smaller board can improve company financial performance and it is easier for CEO to monitor when the size is less than seven or eight directors.

With regards to diversity, many countries have adopted policies to increase the participation of women as members of board of directors. Norway, for instance, has a regulation that requires 40 percent of the firm's directors to be women (Rose, 2007). Spain has also passed legislation that requires certain quota of board members to be given to women (Adam and Ferreira, 2009). These policies are based on the notion that the presence of women in board of director will positively affect management practices that create value to shareholders and increase company's performance. Nevertheless, Campbell and Mínguez-Vera (2008) argued that if the inclusion of women in board of directors brings a different perspective from their male counterpart in the decision making processes, it would enhance shareholder values; but on the other hand, if the inclusion is motivated by societal pressure for greater gender equality, it might have a negative impact on firm's performance.

Previous researches show varying results of the relationship between board size and women participation on board with firm performance. For instance, research by Eisenberg, Sungren and Wells (1997) provide evidence that there is negative correlation between company profit and board size, while Shukeri et al. (2012) found that companies have better performance in term of Return on Equity (ROE) when the board size is larger. Similarly, in term of women on board, Carter et al. (2010) show that gender diversity has positive effect on financial performance and company financial performance in term of company value. On the contrary, a study by Fauzi and Locke (2012) found that the presence of women in board of director harms financial performance.

The opposing results from previous researches might due to varying context of studies. The study by Shukeri et al. (2012) for instance, randomly selected public-listed companies in each sector in Malaysia as the research subject, while the study by Fauzi and Locke (2012) observed 79 New Zealand public-listed companies from six industries classifications. This also is consistent to what had been mentioned by Fauzi and Locke (2012) that the nature of prevailing governance system for each country affects the different result. As such, the researchers of this study acknowledge that there is a need to conduct study in investigating the impact of board size and gender diversity in more specific area, i.e. to focus the research on a single sector or industry, and in a single geographical area.

Hence, this study focuses on privately held companies that involve in Malaysian education sector (here in after referred to as "private education" companies or sectors), which comprises of, but not limited to kindergartens, primary and secondary schools, institutions of higher learning 
(IHLS), driving schools, tuition center, and all other educational service providers. Malaysia is different many of part of the world where the private education companies are profit oriented. Private education companies have different corporate governance structure compares to other sectors whereby the composition of board of directors will consist more women director; will give new insight how the board of directors' composition in private education companies affect the company performance. Until now, there is no empirical study have been done to examine the impact of board composition in private education companies. The data of private education companies in not publicly available which make less researchers focus on this sector. However, private education companies need submit their financial statements to Companies Commission of Malaysia (CCM). Research on board structure in the private education companies could bring significant interests to various stakeholders especially in helping to determine the impact of board size and gender boardroom diversity policy and corporate performances. The primary objective of this study, therefore, is to determine the relationship board structure in term of board size and woman on board and company performance of the private education companies in Malaysia.

\section{Literature Review}

Since the introduction of the Private Higher Education Act (1996), private IHLs has been growing in numbers and the sector keep attracting new participants (Oxford Business Group, n.d.). According to the Ministry of Higher Education, as of December 2015, there are 513 private IHLs in Malaysia, of which 111 are private universities with a status of either University or University College, and the remaining 402 are private colleges, attracting more than 240,000 local students and more than 49,000 international students. Meanwhile, in primary and secondary education, there are more than 500 private schools, of which consists of local private schools, international schools, Islamic schools and Chinese Independent High Schools, attracting 145,000 students between seven to 17 years old (Ministry of Education Malaysia, 2013). Other than these two major segments, there are 166 registered driving schools in Malaysia (Ahmad et al, 2011) and a countless number of tuition centers throughout the country that make up the private education sectors. With such high number of participants in Malaysian private education sector, rivalry among private education institutions would be expected, and in ensuring sustainability and profitability of the company, factors that impact the firm's performance should be studied, including the composition of board.

Board size refers to the total number of members with voting rights on the board of directors. Hussain and Mustafa (2012) mentioned that the size is referred to the total number of the directors in the board, and in this context, there could be large and small size of the board of directors based on its number. The roles of the each members of the board are quite different in each organization, generally competent and able to represent the views and opinions and to serve as a strategic link between the organization and its environment (Brown, 2005; Hillman and Dalziel, 2003).

There are contrasting views on how board size is impacting the firm performance. Jensen (2012), for instance argued that smaller board can improve company financial performance and it is 
easier for the CEO to monitor when the size is less than seven or eight directors. Yermark (1996) and Jensen (1993) also mentioned about that the larger board size is, the more problems in communication and coordination it would create. These views are consistent with the evidence from Eisenberg et al. (1997) and Yermack (1996), who's found negative relationship between board size and company value of large US companies.

Contrary to the above, Alkdai, and Hanefah (2012) argued that the greater numbers of members on the board is, the higher likelihood to have an effective monitoring and make better decisions. Druckeriv (1992) also claimed that the company performance is better when the board is larger over smaller board as the larger board possessed more expertise in information and knowledge compare to smaller board. Furthermore, Rahman and Ali (2006) quoted that the large and powerful board helps to strengthen the link between organizations and their environments, provide counsel and commend regarding strategic options for the firm and play a crucial role in constructing corporate identity. All these is consistent with the evidence by a study made by Shukeri et al. (2012) that found that companies have better performance in term of Return on Equity (ROE) when the board size is larger. They claimed that the large board is effective in management control to mitigate conflict of interest of managers. Despite the varying views and evidences on how board size affects the firm's performance, the researchers assume that a large board provides more expertise, experience and access to resources among other things, which helps them better in overseeing the management of the firm.

$\mathrm{H}_{1}$ : There is a significant relationship between board size and the firm's corporate performance.

Bringing woman in the in a board of director has recently become one of most discussed topic, not only among practitioners, but also at policy making level and societal level. Most of policy maker favors the argument that companies with more woman on board perform better (Adam, 2016). In New Zealand for example, the New Zealand Securities Commission (NZSC) is trying to push the inclusion of women on boards and requires all listed-companies to declare the number of women on their boards from the 2012 fiscal year (Fauzi and Locke, 2012). Countries such as Norway, Iceland and Spain have taken a further step ahead by having quota of a $40 \%$ for women in board (Fauzi and Locke, 2012). Although there is no such quota has been imposed in Malaysia, the Malaysian government has targeted to achieve 30\% women representative in 2016. Currently, the number of women on corporate board in Malaysian public listed companies is very low which on average only two women in every three corporate board (Yusof and Ramin, 2013). In the US meanwhile, women held 14.8 percent of Fortune 500 board seats in 2007 (Catalyst, 2007) and there are estimated of 8.7 percent, 10.6 percent, 0.4 percent and 8.0 percent of women directors in Australia, Canada, Japan and Europe respectively (Equal Opportunity for women in the Workplace Agency, 2016)

Participation of women in board brings many advantages to firms. To look from resource dependency perspective, diversity would provide access to additional resources, and stakeholders would also prefer to have a diverse members in board to represent different stakeholders (Keasey et al. 1998). Therefore, the inclusion of women in board would bring 
additional and differing viewpoint from male directors. Smith et al. (2006) point out women directors understand market condition better than men, and bring more creativity and quality to board decision making. Higher gender diversity on the board produce a better development of company and improve company performance. The involvements of women in board also would explore external talent pool. In addition, the number of women in board may positively influence the career development of women in lower position by motivate them as role model.

Furthermore, the external environment also brings the attention to include women in board. For example, in respond to many corporate scandals in the early year 2000 in UK, Higgs and Tyson (2003) argued that the board should be more gender diverse in employing board of directors. Women are wanted in position of leadership in condition of downturn and the effect that presence of women on board could be perceived by shareholder that significant change on the way and making them more confident in the company success which is increases in share price (Ryan and Haslam, 2005). This view in sync with a study conducted by Leeds University Business School which was summarized by The Times of London (2011) that shows that having at least one women director decrease the risk of a company's going bust by about 20 percent.

The advantage of having more women in board may derive from the personality and attributes that a woman brings. There would be more demand on facts and details when more women on the board. Normally, women more interested in getting facts, ask more questions and interested to know how the organization works. They want to be more hard- working, responsible and honest about their weakness (Sweetman, 2010). Women also have different behavior than men with respect to the attendance behavior (Adams and Ferreira, 2008). Galbreath (2011) found there is positive link between woman and economic growth because woman more likely able to engage with various stakeholders and cope to their needs.

Prior studies have investigated gender diversity in board of directors and its relation on company performance. Erhardt et al. (2003) found that the diversity in board of director was positively associated with both Return on Asset (ROA) and Return on Equity (ROE). A similar study conducted by Adams and Ferreira, (2009) concluded that there was a significant positive relation between gender diversity and ROA and a higher gender diversity in top management would results in higher level of company performance.

Similar to the board size, there are contrasting view and evidence on how women participation on board would affect firm's performance. Wang and Clift (2009) and Shukeri, et al. (2012) found that there is no strong relationship between gender diversity on the board and financial performance due to lower number of women on directorship. This is also consistent with a recent research by Mehrotra (2016) that do not find any relationship between woman and financial performance. Interestingly, a study by Fauzi and Locke (2012) on public-listed companies in New Zealand found that the presence of women is actually harmful to the financial performance. They argued that the result may due to the fact that the involvement of women is still rare in New Zealand listed companies. 
INTERNATIONAL JOURNAL OF ACADEMIC RESEARCH IN PROGRESSIVE EDUCATION AND DEVELOPMENT

Vol. 8, No. 4, 2019, E-ISSN: 2226-6348 C 2019 HRMARS

$\mathrm{H}_{2}$ : There is a significant relationship between women on board and the firm's corporate performance.

\section{Methodology}

Our sample is private education companies registered in Companies Commission of Malaysia (CCM). We collected all the private educational companies' financial data from 2011-2013. The final sample data of this study consists of 100 private education companies with 280 observations. Definitions of all variables are stated in Table 1.

\section{TABLE 1: DEFINITION OF VARIABLES USED IN THIS STUDY}

\begin{tabular}{ll}
\hline Variable & Definition \\
\hline $\begin{array}{l}\text { Corporate performance } \\
\text { measurement } \\
\text { Roa }\end{array}$ & $\begin{array}{l}\text { Roe (return on assets), calculated as profit after tax for the year } \\
\text { scaled to the total assets at the end of financial year. } \\
\text { Roe (return on equity), calculated as profit after tax for the year } \\
\text { scaled to the total shareholders' equity at the end of financial } \\
\text { year. }\end{array}$
\end{tabular}

Board structure (independent variable)

Board Total number of board members at the beginning of the financial year, extracted data from $\mathrm{ccm}$

Woman

Total of woman directors scaled by total number of board members at the beginning of the financial year, extracted data from $\mathrm{ccm}$.

\section{Control variables}

Lev

Leverage (lev), calculated as total liabilities at the beginning of the financial year scaled by the total assets at that date, and extracted data from $\mathrm{ccm}$.

Size

Company's size (size), calculated as the natural log of total assets at beginning of the financial year extracted data from $\mathrm{ccm}$.

Liq

Liquidity (liq), calculated as total current assets at the beginning of the financial year scaled by total current assets at that date, extracted data from $\mathrm{ccm}$.

Fage

Age of the firm (fage), calculated as the financial year of the study subtract the year of incorporation of the company, extracted data from ccm. 
In this study, the multiple regression models had been used to test the hypothesis. Multiple regression analysis is approach that determine the linear relationship between the dependent variable and independent variables because these approach is better in order to examine the significantly of the variables. The objective has stated earlier which is to investigate the relationship between company performance with board structure which are bored size and woman on board. The model of these research studies has been modified based on the model used by shukeri et al. (2012). Based on their study, they used few variables that also related to this study such as board size, woman on board. In our study, we add control variable such as leverage, firm size, liquidity and age of firm. In this study has focus data that only available retrieve from ccm such financial data, board directors background, company incorporation date and status.

\section{The Function is as Follow}

Corporate Performance $(C p)=$ F (Board Size, Woman On Board, Gearing, Size, Liquidity, Age)

We derive the function become regression estimation model as follow

$\mathrm{CP}_{\mathrm{I}, \mathrm{T}}=\beta_{0}+\beta_{1} \mathrm{BSIZE}_{i, t}+\beta_{2} \mathrm{WOMAN}_{\mathrm{I}, \mathrm{T}}+\beta_{3} \mathrm{LEV}_{i, t}+\beta_{4} \mathrm{FSIZE}_{i, t}+\beta_{5} \mathrm{LIQ}_{i, t}+\beta_{5} \mathrm{FAGE}_{i, t}+\varepsilon$

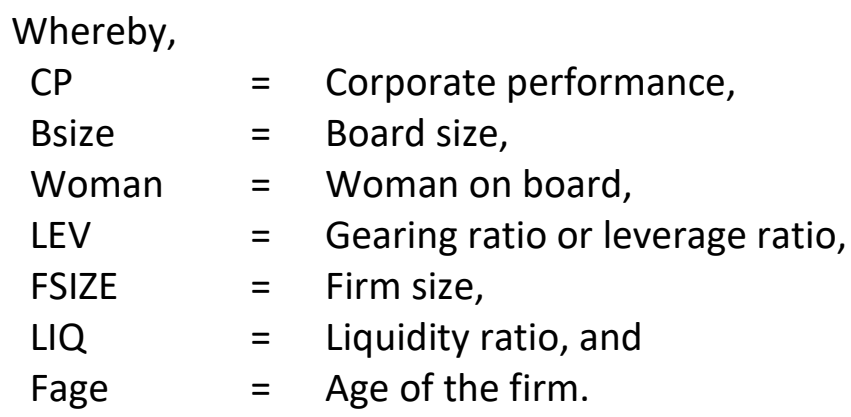

\section{Results and Discussion}

Table 2 shows that the mean of the Return on Assets (ROA) is $2.0829 \%$ measure by net profit after tax divided by total assets while the return on Equity on Equity (ROE) is higher than ROA. The mean of ROE is equal to $4.3372 \%$. Board Size (BSSIZE) show the minimum number of directors is 2 directors and the maximum is 10 directors in private company in education industry. The average woman sitting on board is around $40.42 \%$. In this sample the number woman sit on the corporate board private education companies is range of 1 to 5 people. The Leverage (LEV) is measure by total debts to total assets is average value equal to $55.72 \%$ in this sample. The minimum of Firm Size (FSIZE) is 8.2071 and the maximum is 3.1013 . The FSIZE being calculated as the natural log of total assets at beginning of the financial year extracted data from CCM. The liquidity (LIQ) is calculated by total current assets at the beginning of the financial year scaled by total current assets at that date, extracted data from CCM. It is equal to 9.0762 average year's value. The last variable is Firm Age (FAGE) is start from 1 year to 31 years old age of companies. 
Table 2

\begin{tabular}{|c|c|c|c|c|c|}
\hline Variables & Mean & Median & Maximum & Minimum & $\begin{array}{l}\text { Std. } \\
\text { Dev. }\end{array}$ \\
\hline ROA & 2.0829 & 0.9929 & 54.268 & 0 & 5.0291 \\
\hline ROE & 4.3372 & 1.0377 & 59.2609 & -26.873 & 10.4705 \\
\hline Board Size (BSIZE) & 3.0536 & 3 & 10 & 2 & 1.3863 \\
\hline $\begin{array}{l}\text { \% Women on board } \\
\text { (WOMEN) }\end{array}$ & 0.4042 & 0.5 & 1 & 0 & 0.2846 \\
\hline Number of women on board & 1.2357 & 1 & 5 & 0 & 1.0203 \\
\hline Women on board (Yes/No) & 0.7607 & 1 & 1 & 0 & 0.4274 \\
\hline Leverage (LEV) & 0.5572 & 0.4913 & 3.1013 & 0.0083 & 0.4588 \\
\hline Firm Size (FSIZE) & 12.5648 & 12.5865 & 16.283 & 8.2071 & 1.4974 \\
\hline Liquidity (LIQ) & 9.0762 & 1.5768 & 98.14 & 0 & 17.799 \\
\hline Firm Age (FAGE) & 2.5143 & 2 & 31 & 1 & 3.0065 \\
\hline
\end{tabular}

\section{Summary Statistics}

The table presents the summary statistics for the variables used in this study. This study examines 100 Malaysia private companies from year 2011-2013 with a total of 280 observations. The dependent variables are ROA and ROE, which are used to proxy corporate performance. The explanatory variables are board size and women on board and our control variables consist of leverage, firm size, liquidity and firm age. The total observations in our study is 280 . anagement directly through their ownership or indirectly by trading their shares. Future research that tries to investigate the relationship between ownership with

Company performance can examine different industry effects and utilize other performance Measures such as earning per share (EPS), return on investments (ROI), share price and economic value added (EVA) and to consider also the nonlinearity and endogeneity issues as highlighted by recent studies.

management directly through their ownership or indirectly by trading their shares. Future research that tries to investigate the relationship between ownership with

Company performance can examine different industry effects and utilize other performance Measures such as earning per share (EPS), return on investments (ROI), share price and economic value added (EVA) and to consider also the nonlinearity and endogeneity issues as highlighted by recent studies.

From the Table 3, the dependent variable which is ROA is correlated with ROE, LIQ at $1 \%$ significant level. It also has significant negative relationship with FSIZE at the same significant level. The ROA has no significant relationship with other varaiables such as BSIZE, WOMEN, LEV, and FAGE . Followed by ROE, ROE has no significant negartive relationship with all variables.In relation to independent variable and control variables, BSIZE is positively correlated with LEV, FSIZE at $1 \%$ significant level and LIQ at 5\% significant level. WOMEN has no correlation with all 
INTERNATIONAL JOURNAL OF ACADEMIC RESEARCH IN PROGRESSIVE EDUCATION AND DEVELOPMENT

Vol. 8, No. 4, 2019, E-ISSN: 2226-6348 @ 2019 HRMARS

control variables. LEV is negative correlated with LIQ at $1 \%$ significant level. FSIZE is negative correlated with LIQ at $5 \%$ significant level and positive orrelated with FAGE at 5\% significant level.

\section{Table 3}

\section{Correlations}

This table presents the correlation coefficient among all the variable including dependent variable (corporate performance proxy by ROA and ROE), explanatory variables (Board Structure proxy by Board size and Women on board), and the control variables (leverage, Firm Size, Liquidity and Firm Age).

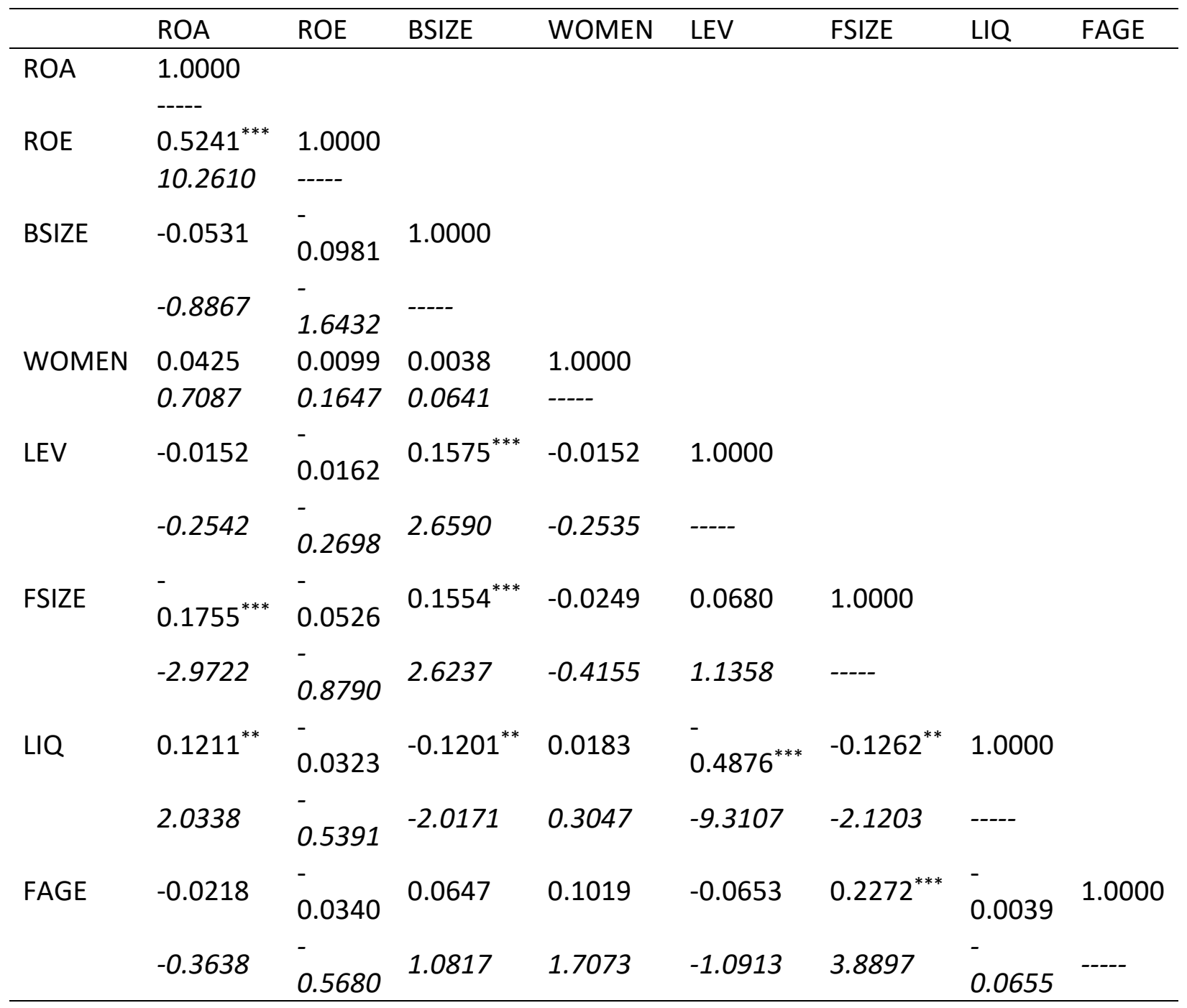

$*, * * * * *$ denote the correlation is significant at $10 \%, 5 \%$ and $1 \%$ level respectively. $T$ statistics are reported in parentheses.

In the Table 4, model 1 is regression model that consist one independent variable which is board size (BSIZE) and all control variables such as leverage (LEV), firm's size (FSIZE), liquidity (LIQ), and firm's age (Fage) while model 2 is regression model that consist one independent variable which 
Vol. 8, No. 4, 2019, E-ISSN: 2226-6348 @ 2019 HRMARS

is woman on board (WOMAN) and all control variables. The dependent variable in the panel $A$ is return on Assets. The model 3 is regression model that consist all varaibles. From the above result of panel $A$, the Bsize has negative significant relationship with ROA at $1 \%$ significant level. This result is consistent research find by Azeez (2015). Many researchers argue that a firm is more difficulty to manage when the board size is larger. Other researcher (Fauzi and Locke 2012) found positive relationship between the Board and financial performance. Mnsari (2015) finds not significant negative relationship between board and financial performance while Mehrotra (2016) finds not significant positive relationship between board and financial performance.

The second independent variable which is WOMAN has positive significant relationship with ROA at same level. This may due to argument that woman sitting on board are more effective than men (L.Tyson, 2003, Adams \& Ferreira, 2008, Galbreath, 2011). However, the result not aligns with Fauzi and Locke (2012) found negative relationship between Woman and financial performance. Mehrotra (2016) and Shukeri et al. (2012) do find not significant relationship positive between Woman and performance.

\section{Table 4}

\section{Result for Corporate performance and Board Structure}

The table presents results for corporate performance proxy by ROA. The results presented are based on the models below:

Model I: $\mathrm{CP}_{\mathrm{i}, \mathrm{t}}=\alpha+\beta_{1}$ BSIZE $_{\mathrm{i}, \mathrm{t}}+\beta_{2} \mathrm{LEV}_{\mathrm{i}, \mathrm{t}}+\beta_{3} \mathrm{FSIZE}_{\mathrm{i}, \mathrm{t}}+\beta_{4} \mathrm{LIQ}_{\mathrm{i}, \mathrm{t}}+\beta_{5} \mathrm{FAGE}_{\mathrm{i}, \mathrm{t}}+\varepsilon$

Model II: $\mathrm{CP}_{\mathrm{i}, \mathrm{t}}=\alpha+\beta_{1}$ WOMEN $_{\mathrm{i}, \mathrm{t}}+\beta_{2} \mathrm{LEV}_{\mathrm{i}, \mathrm{t}}+\beta_{3} \mathrm{FSIZE}_{\mathrm{i}, \mathrm{t}}+\beta_{4} \mathrm{LIQ}_{\mathrm{i}, \mathrm{t}}+\beta_{5} \mathrm{FAGE}_{\mathrm{i}, \mathrm{t}}+\varepsilon$

Model III: $\mathrm{CP}_{\mathrm{i}, \mathrm{t}}=\alpha+\beta_{1}$ BSIZE $_{\mathrm{i}, \mathrm{t}}+\beta_{2}$ WOMEN $_{i, \mathrm{t}}+\beta_{3} \mathrm{LEV}_{\mathrm{i}, \mathrm{t}}+\beta_{4} \mathrm{FSIZE}_{\mathrm{i}, \mathrm{t}}+\beta_{5} \mathrm{LIQ}_{\mathrm{i}, \mathrm{t}}+\beta_{6} \mathrm{FAGE}_{\mathrm{i}, \mathrm{t}}+\varepsilon$

\begin{tabular}{lrrr}
\hline & Model I & Model II & \multicolumn{2}{c}{ Model III } \\
\hline BSIZE & $-0.1604^{* * *}$ & & $-0.1480^{* * *}$ \\
WOMEN & -5.3655 & $0.7750^{* * *}$ & $0.6483^{* * *}$ \\
LEV & & 7.4120 & 5.6414 \\
& & $0.5444^{* * *}$ & $0.6283^{* * *}$ \\
FSIZE & $0.5210^{* * *}$ & 4.8156 & 5.4318 \\
& 4.4134 & $-0.4538 * * *$ & $-0.4335^{* * *}$ \\
LIQ & $-0.4634^{* * *}$ & -14.0610 & -14.1495 \\
& -14.7054 & 0.0074 & 0.0033 \\
FAGE & 0.0074 & 1.2049 & 0.5052 \\
& 1.1465 & $0.0200 *$ & $0.0280^{* * *}$ \\
C & $0.0353^{* * *}$ & 1.8524 & 2.6694 \\
& 3.4744 & $6.6109 * * *$ & $6.7500 * * *$ \\
\hline Adjusted R-square & $7.5442 * * *$ & 14.5769 & 15.7838 \\
F-statistic & 17.5216 & 0.5354 & 0.5503 \\
Prob(F-statistic) & 0.5210 & 66.9330 & 59.3322 \\
Observations & 63.2267 & 0.0000 & 0.0000 \\
\hline
\end{tabular}

*,**,*** denote the correlation is significant at $10 \%, 5 \%$ and $1 \%$ level respectively. T-statistics are reported in parentheses. 
All control variables has significant relationship with ROA except LIQ. Start with LEV, it has significant relationship with ROA at $1 \%$ significant level. Jensen (1986) said that leverage reduces the free cash flow problems therefore increase firm's performance. Study made by Mangena (2012) show that the leverage has no significant relationship with financial performance. Fauzi and Locke (2012) find not significant positive relationship between Gearing and financial performance. Followed by FSIZE has negative relationship with ROA at at $1 \%$ significant level. Similar result found by Mnasri (2015). When the firm's size is larger this make difficult in monitoring manger because of free rider problems and the more time spent on decision-making (Jensen, 1993) and it also may incur inefficiencies that result in bad performance (Klapper and Love, 2004). The result contracting with research found by Azeez (2015), Fauzi and Locke (2012). They find significant positive relationship between firm size and financial performance. LIQ has negative relationship with no significant level. Lastly, FAGE has positive relationship with ROA. It has 1\% significant level in Model 1 and Model 2 and 10\% in Model 3. Hopenhanyn (1992), proven that older firm can be profitable compare to younger firm due to experience and efficientcy. Reseach made by Azeez (2015) show that no significant negative relationship between AGE and ROA.

We conduct further study by changing the independent varible corporte performance proxy to Return on Equity (ROE). The BSIZE is still has significant positive relationship with ROE at $1 \%$ significant level. However, we could not find any significant positive relationship WOMAN and ROE. The leverage has no significant relationship with ROE. It has negative effect on ROE in Model 1 and Model 3 and has opposite effect on ROE in Model 2. FSIZE is also has negaive effect on corporate performance with no significant level at all the model in Panel B. Liquidity has negative relationship with ROE at 1 significal level in all model in Panel B. Finally, the FAGE has significant negative relationship with ROE at 1\% significant level in model 1 and Model 3 and 5\% significant level in model 2. Loderer and Waelchli (2009) stressed that older firm have a problem rigidity over time which couse slow growth and lead decrease in reseach and developement (R\&D) activities.

\section{Table 5}

\section{Additional Result for Corporate performance and Board Structure}

The table presents results for corporate performance proxy by ROE with three models. The results presented are based on the models below:

Model I: $\mathrm{CP}_{\mathrm{i}, \mathrm{t}}=\alpha+\beta_{1}$ BSIZE $_{\mathrm{i}, \mathrm{t}}+\beta_{2} \mathrm{LEV}_{\mathrm{i}, \mathrm{t}}+\beta_{3} \mathrm{FSIZE}_{\mathrm{i}, \mathrm{t}}+\beta_{4} \mathrm{LIQ}_{\mathrm{i}, \mathrm{t}}+\beta_{5} \mathrm{FAGE}_{\mathrm{i}, \mathrm{t}}+\varepsilon$ Model II: $\mathrm{CP}_{\mathrm{i}, \mathrm{t}}=\alpha+\beta_{1} \mathrm{WOMEN}_{\mathrm{i}, \mathrm{t}}+\beta_{2} \mathrm{LEV}_{\mathrm{i}, \mathrm{t}}+\beta_{3} \mathrm{FSIZE}_{\mathrm{i}, \mathrm{t}}+\beta_{4} \mathrm{LIQ}_{\mathrm{i}, \mathrm{t}}+\beta_{5} \mathrm{FAGE}_{\mathrm{i}, \mathrm{t}}+\varepsilon$ Model III: $\mathrm{CP}_{\mathrm{i}, \mathrm{t}}=\alpha+\beta_{1}$ BSIZE $_{\mathrm{i}, \mathrm{t}}+\beta_{2}$ WOMEN $_{i, t}+\beta_{3} \mathrm{LEV}_{\mathrm{i}, \mathrm{t}}+\beta_{4} \mathrm{FSIZE}_{\mathrm{i}, \mathrm{t}}+\beta_{5} \mathrm{LIQ}_{\mathrm{i}, \mathrm{t}}$

$$
+\beta_{6} \mathrm{FAGE}_{\mathrm{i}, \mathrm{t}}+\varepsilon
$$


INTERNATIONAL JOURNAL OF ACADEMIC RESEARCH IN PROGRESSIVE EDUCATION AND DEVELOPMENT

Vol. 8, No. 4, 2019, E-ISSN: 2226-6348 @ 2019 HRMARS

\begin{tabular}{lllc}
\hline & Model I & Model II & Model III \\
\hline BSIZE & $-0.3656^{* * *}$ & & $-0.3460^{* * *}$ \\
WOMEN & -3.1752 & & -2.8750 \\
& & & 0.6817 \\
LEV & & 1.1415 & 0.9274 \\
& -0.1237 & 1.5832 & -0.1030 \\
FSIZE & -0.2288 & 0.1371 & -0.1930 \\
& -0.0696 & 0.2368 & -0.0742 \\
LIQ & -0.4948 & -0.1674 & -0.5307 \\
& $-0.0473^{* * *}$ & -1.1380 & $-0.0463^{* * *}$ \\
& -4.6883 & $-0.0464 * * *$ & -4.6749 \\
FAGE & $-0.0328 * *$ & -4.4610 & $-0.0414^{* *}$ \\
& -2.2200 & $-0.0473 * * *$ & -2.3805 \\
C & $5.2609 * * *$ & -2.6506 & $4.9848^{* * *}$ \\
& 2.9551 & $4.8271^{* *}$ & 2.7774 \\
\hline Adjusted R-square & 0.2460 & 2.5133 & 0.2570 \\
F-statistic & 19.2088 & 0.2393 & 17.0913 \\
Prob(F-statistic) & 0.0000 & 18.5620 & 0.0000 \\
Observations & 280 & 0.0000 & 280 \\
\hline
\end{tabular}

\section{Conclusion}

Conclusively, based on the findings of this study, there is an empirical insight of the relationship between board structure measure by board size and women on board and company performance in Malaysian private education firms. After controlling, leverage, size, liquidity and age, the finding reveals that the larger board size has significant negative impact on the financial performance of private education companies. A firm is more difficult to manage when the board size is larger. Many sectors other than private education companies are less likely to employ more women which make women have less influence in corporate board decision making. Increase involvement of women in private education company in some extent improves the company performance. This may due to argument that women are more effective in decision making than men. Hence, women's influence and involvement are higher in education firms compared to other industries. Perhaps, bringing more women on board in the company for other sectors could produce the same result.

Lack of research governance in the private education sector firms as pointed previously is one of the major challenges to determine factors that may contribute to company performance. This study is limited to the independent variables which are board size and woman on board on company performance. The study could be extended with variables such as ownership, board meeting, director social network and other on company performance that could give significant interest of many stakeholders such as academician, government, and ethic. Furthermore, if the 
sample can be expanded longer period may provide generalized result. Future research that tries to investigate the relationship between board structure on company performance can examine different industry effects and utilize other performance measures such economic value added (EVA), and financial growth to provide the effect of board structure from different perspectives.

\section{References}

Adams, R. B. (2016). Women on boards: The superheroes of tomorrow?. The Leadership Quarterly, 27(3), 371-386.

Adams, R. B., \& Ferreira, D. (2009). Women in the boardroom and their impact on governance and performance. Journal of Financial Economics, 94(2), 291-309.

Ahmad, M. S., Isah, N., Osman, M. R., \& Abas, F. (2011). Pembangunan Kriteria Penggredan Institut Memandu di Malaysia. Retrieved March 1, 2014, from file:///C:/Users/user/Downloads/MRR 02-2011_Pembangunan kriteria penggredan institut memandu di malaysia_170ct2011.pdf.

Alkdai, H. K., \& Hanefah, M. M. (2012). Board of directors' characteristics and value relevance of accounting information in Malaysian shariah-compliant companies: a panel data analysis. Economics and Finance Review, 2(6), 31-44.

Azeez, A. A. (2015). Corporate governance and firm performance: evidence from Sri Lanka. Journal of Finance, 3(1), 180-189.

Brown, W. A. (2005). Exploring the association between board and organizational performance in nonprofit organizations. Nonprofit Management and Leadership, 15(3), 317-339.

Campbell, K., \& Mínguez-Vera, A. (2008). Gender diversity in the boardroom and firm financial performance. Journal of Business Ethics, 83(3), 435-451.

Carter, D. A., D'Souza, F., Simkins, B. J., \& Simpson, W. G. (2010). The gender and ethnic diversity of US boards and board committees and firm financial performance. Corporate Governance: An International Review, 18(5), 396-414.

Catalyst. (2007). Census of Women Board Directors of the Fortune 500. Equity in Business Leadership. Retrieved March 1, 2014, from http://www.catalyst.org/system/files/census_board_final.pdf.

Dutta, P., \& Bose, S. (2007). Gender diversity in the boardroom and financial performance of commercial banks: Evidence from Bangladesh, The Cost and Management 34(6), 70-74.

Eisenberg, T., Sundgren, S., \& Wells, M. T. (1998). Larger board size and decreasing firm value in small firms. Journal of Financial Economics, 48(1), 35-54.

Equal Opportunity for Women in the Workplace Agency (2006). Retrieved March 1, 2014, from https://www.wgea.gov.au/sites/default/files/Final_Annual_Report0708[1].pdf.

Erhardt, N. L., Werbel, J. D., \& Shrader, C. B. (2003). Board of director diversity and firm financial performance. Corporate governance: An International Review, 11(2), 102-111.

Fama, E. F., \& Jensen, M. C. (1983). Separation of ownership and control. The Journal of Law and Economics, 26(2), 301-325.

Fauzi, F., \& Locke, S. (2012). Board structure, ownership structure and firm performance: A study of New Zealand listed-firms. Asian Academy of Management Journal of Accounting and Finance 8(2), 43-67. 
INTERNATIONAL JOURNAL OF ACADEMIC RESEARCH IN PROGRESSIVE EDUCATION AND DEVELOPMENT

Vol. 8, No. 4, 2019, E-ISSN: 2226-6348 @ 2019 HRMARS

Higgs, D. (2003). Review of the Role and Effectiveness of Nonexecutive Directors. Retrieved March 1, 2014, from http://www.citationmachine.net/bibliographies/511592174?new=true.

Hillman, A. J., \& Dalziel, T. (2003). Boards of directors and firm performance: Integrating agency and resource dependence perspectives. Academy of Management Review, 28(3), 383396.

Hillman, A. J., Cannella, A. A., \& Paetzold, R. L. (2000). The resource dependence role of corporate directors: Strategic adaptation of board composition in response to environmental change. Journal of Management Studies, 37(2), 235-256.

Hopenhayn, H. A. (1992). Entry, exit, and firm dynamics in long run equilibrium. Econometrica: Journal of the Econometric Society, 60(5), 1127-1150.

Hwang, I., Kim, H., \& Pae, S. (2014). Equity-based compensation for outside directors and cost of equity capital. Journal of Applied Business Research, 30(1), 15-26.

Jensen, M. C. (1986). Agency costs of free cash flow, corporate finance, and takeovers. The American Economic Review, 76(2), 323-329.

Jensen, M. C. (1993). The modern industrial revolution, exit, and the failure of internal control systems. the Journal of Finance, 48(3), 831-880.

Abor, J. (2005). The effect of capital structure on profitability: an empirical analysis of listed firms in Ghana. The Journal of Risk Finance, 6(5), 438-445.

Keasey, K., Thompson, S., \& Wright, M. (1998). Corporate governance, economic, management, and financial issues. Managerial Auditing Journal, 13(6), 390-391.

Klapper, L. F. and I. Love (2004). Corporate governance, investor protection, and performance in emerging markets. Journal of Corporate Finance 10(5), 703-728.

Kula, V. (2005). The impact of the roles, structure and process of boards on firm performance: Evidence from Turkey. Corporate Governance: An International Review, 13(2), 265-276.

Loderer, C. F., \& Waelchli, U. (2010). Firm age and performance. Available at SSRN 1342248.

Ministry of Education Malaysia (2013). Malaysia Education Blueprint 2013-2025. Retrieved March 1, 2014, from https://www.moe.gov.my/muat-turun/penerbitan-danjurnal/dasar/1207-malaysia-education-blueprint-2013-2025/file.

Mangena, M., Tauringana, V., \& Chamisa, E. (2012). Corporate boards, ownership structure and firm performance in an environment of severe political and economic crisis. British Journal of Management, 23(1), 23-41.

Mehrotra, S. (2016). The Nature of Corporate Board Structure and Its Impact on the Performance of USA Listed Firms. IUP Journal of Corporate Governance, 15(1), 30-45.

Mnasri, K. (2015). Ownership Structure, Board Structure And Performance in the Tunisian Banking Industry. Asian Academy of Management Journal of Accounting and Finance, 11(2), 57-82.

Oxford Business Group (n.d.). Malaysia Education Reforms Result in More Opportunities for Private Sector Participation. Retrieved March 1, 2016, from https://oxfordbusinessgroup.com/overview/working-together-widespread-reformsresult-more-opportunities-private-sector-participation.

Rahman, R. A. and F. H. M. A. (2006). Board, audit committee, culture and earnings management: Malaysian evidence. Managerial Auditing Journal, 21(7), 783-804. 
Rose, C. (2007). Does female board representation influence firm performance? The Danish evidence. Corporate Governance: An International Review, 15(2), 404-413.

Ryan, M. K., \& Haslam, S. A. (2005). The glass cliff: Evidence that women are over-represented in precarious leadership positions. British Journal of Management, 16(2), 81-90.

Shukeri, S. N., Shin, O. W., \& Shaari, M. S. (2012). Does board of director's characteristics affect firm performance? Evidence from Malaysian public listed companies. International Business Research, 5(9), 120-127.

Smith, N., Smith, V., \& Verner, M. (2006). Do women in top management affect firm performance? A panel study of 2,500 Danish firms. International Journal of productivity and Performance management, 55(7), 569-593.

Sweetman, K. (2010). How Women Have Changed Norway's Boardrooms. Retrieved March 1, 2014, from http://www.diversityspectrum.com/index.php/The-Boardroom/How-women have-Ch.

Sweigart, A. (2012). Women on board for change: The Norway model of boardroom quotas as a tool for progress in the United States and Canada. Northwestern Journal of International Law \& Business, 32(4), 81-105.

Tyson, L. (2003). The Tyson Report on the Recruitment and Development of Nonexecutive Directors. Retrieved March 1, 2016, from www.womenonboards.co.uk/resourcecentre/reports/.../TysonReport.pdf.

Wang, Y., \& Clift, B. (2009). Is there a "business case" for board diversity? Pacific Accounting Review, 21(2), 88-103.

Yermack, D. (1996). Higher market valuation of companies with a small board of directors. Journal of Financial Economics, 40(2), 185-211

Yusoff, W. F. W., \& Ramin, A. K. (2013, December). Women on Corporate Boards: Malaysian Perspectives. In 2nd International Conference on Technology Management, Business and Entrepreneurship, Melaka, Malaysia (Vol. 5, pp. 292-300) 